\title{
Information technology adoption by small business: An empirical study
}

\author{
J.Y.L. Thong and C.S. Yap \\ National University of Singapore \\ Department of Information Systems and Computer Science \\ Lower Kent Ridge Road, Singapore 119260 \\ (email: jthong@iscs.nus.sg; yapcs@iscs.nus.sg)
}

\begin{abstract}
Drawing upon theories from the technological innovation literature, this study examines the relationship between various contextual factors (CEO innovativeness, information intensity, attitude towards IT adoption, IT knowledge, and competition) and IT adoption in small businesses. The results show that small businesses are more likely to adopt IT when they have more innovative CEOs, positive attitude toward adoption of IT, and greater IT knowledge. While CEO innovativeness and attitude toward IT adoption are important determinants of the decision to adopt, they do not affect the extent of IT adoption subsequently. The extent of IT adoption is mainly determined by the level of IT knowledge.
\end{abstract}

\begin{abstract}
Keywords
Information technology, innovation theories, small businesses, technological innovation
\end{abstract}

\section{INTRODUCTION}

An important and fast growing technological innovation during this century is information technology (IT) in the form of computers (Freeman and Perez, 1988). IT provides an opportunity for businesses to improve their efficiency and effectiveness, and even to gain competitive advantage (Ives and Learmonth, 1984; Porter and Millar, 1985). There are many reported cases in the information systems (IS) literature of the positive contribution of IT to large businesses. With the decreasing cost and ever more powerful user-friendly microcomputers and standard software packages, today the benefits are accessible even to the smallest business. Yet, while large businesses have been using computers for some time, small businesses have been slow in adopting these technological innovations. 
A review of the published literature shows that to-date there has been little empirical research on the determinants of IT adoption in small businesses. Existing studies (Lind et al., 1989; Yap, 1990) tend to concentrate on large businesses, and findings of these studies are unlikely to be applicable to small businesses because of various fundamental differences between large and small businesses (Cohn and Lindberge, 1972; Welsh and White, 1981). In general, small businesses are characterized by financial constraints, lack of internal IT experts, and a short-range management perspective. Further, the research topic - determinants of IT adoption in small business - is not only of theoretical interest, but also has important practical implications. Consulting firms and IT vendors can target their promotional efforts at small businesses that have not computerized but have characteristics of computerized businesses, since this group of businesses is more likely to adopt IT.

As IT is a technological innovation, it may be fruitful to utilize innovation theories as a reference theory for empirical studies of IT adoption. Rogers (1983), an authority on innovation theory, defined an innovation as an idea, practice, or object that is perceived as new by an individual or other unit of adoption. Thus, an innovation is not only a renewal by means of technology, but it can also refer to renewal in terms of thought and action (Poutsma et al., 1987). The innovation itself need not be new as measured by the time of its discovery or invention. It only has to be perceived as new by the unit of adoption (Zaltman et al., 1973). This suggests that an innovation is any product or process which has been put into practice, and is nontrivial to the business. The innovation presents potential adopters with new means of solving problems and exploiting opportunities.

The characteristics of an innovation can be differentiated along four dimensions (Poutsma et al., 1987). First, there are process innovations and product innovations. Process innovations are innovations that improve the production process through the introduction of new methods, machines, or production systems. Process innovations apply not only to the traditional definition of production but also to data processing, distribution, and services. IT adoption and implementation would fall under this category. Product innovations, on the other hand, refers to the development, production, and dissemination of new consumer and capital goods and services. Second, innovations can be either radical (or shock-like) or incremental (or gradual). Basically, radical innovations are fundamental changes that represent revolutionary changes in technology while incremental innovations are minor improvements or simple changes in current technology (Dewar and Dutton, 1986). IT is an example of a radical innovation. For a small business with little IT knowledge, embarking on IT adoption for the first time is nontrivial as there is a lot of uncertainty and risk involved. The adoption of IT is likely to cause changes in work procedures and increase computer anxiety among the employees. Third, innovations can occur due to technology-push or market-pull. Technologypush implies that an innovation is developed and offered in a matured form on the capital goods market. Under pressure exerted by the competing suppliers and the ascribed superiority of the new innovation, the market is necessitated to absorb the new innovation. In a marketpull, a social need is felt, acknowledged, and translated in terms of technical demand. In response to this demand, a new technology is developed. In the case of IT, both technologypush and market-pull have had an effect on the adoption of IT (King et al., 1994). Four, a distinction can be made between planned and incidental innovation. Planned innovations are innovations that are carried out according to plan where the business aims to control the market through its innovation. Innovations are considered incidental when the innovations occurred as a specific reaction of a business to new market demand. Both approaches are applicable for the adoption of IT. 
The technological innovation literature has identified many variables that are possible determinants of organizational adoption of an innovation. This large number of variables suggests that more research is needed to identify the critical ones (Rothwell, 1977). In an agenda for innovation processes research, Eveland et al. (1983) contended that a closer consideration of organizational variables with a primary focus on rigorous empirical studies are warranted. However, some researchers have questioned the possibility of developing a unifying theory of innovation adoption and diffusion that can apply to all types of innovations (Downs and Mohr, 1976; Fichman and Kemerer, 1993; Kimberly and Evanisko, 1981). They argued that a unifying theory may be inappropriate due to the fundamental differences between types of innovations. Fichman and Kemerer (1993) claimed that the variations in innovations (e.g. product vs process; administrative vs technical; incremental vs radical) and the adoption contexts in which they may be applied (e.g. individual vs organizational adoption; autonomous vs nonautonomous adoption decisions; competitive vs noncompetitive adoption environments) are simply too great. In a review of eighteen empirical studies of IT diffusion, Fichman (1992) found that IT innovations may have different levels of knowledge burden and locus of adoption (individual vs organization), and classical innovation theory need to be tailored to the adoption context. In response to the lack of a unifying theory of innovation adoption, it is essential to include the distinctive characteristics of context in the development of a strong theory to study innovation adoption (Fichman and Kemerer, 1993; Tornatzky and Fleischer, 1990; Zmud, 1982).

This paper develops and tests a model of IT adoption in small businesses which contains five contextual variables. The five variables are CEO innovativeness, information intensity, attitude toward adoption of IT, IT knowledge, and competition.

\section{RESEARCH MODEL}

There are two related but distinct research questions: (1) what variables determine the decision of small businesses to adopt IT? and (2) if the decision is to adopt IT, what variables determine the extent of IT adoption? The first research question is concerned with whether a small business is using IT or not while the second research question is concerned with why some small businesses make more use of IT while others less. Based on innovation theories, a model of IT adoption specifically for small businesses was developed (see Figure 1). As this is an early study and the primary purpose is to identify primary relationships, we decided to use a one-stage model relating independent and dependent variables, without any intermediate variables. As more experience is gained, the model can be refined. Each of the variables is discussed below.

\subsection{IT adoption}

The dependent variable is adoption of IT. In this study, adoption of IT is defined as using computer hardware and software applications to support operations, management, and decision-making in the business (Davis and Olson, 1985). This implies that IT is used productively and is not a 'white elephant'. There are two measures for the dependent variable. The first measure, likelihood of IT adoption, was measured as a binary value: whether the business is computerized or not computerized. This measure is commonly used in diffusion 
research (Fichman, 1992). A dichotomous measure was used because the first research question of this study is to identify variables that distinguish a computerized small business from a noncomputerized one. Following the example of Alpar and Reeves (1990), a business is defined as computerized if it uses at least one major software application listed in the software application table (see Appendix A). This list excluded word processing packages. The second measure of IT adoption, extent of IT adoption, was measured by the number of microcomputers in use in each business (Lind et al., 1989). This measure indicates the degree to which IT has been adopted. In the case of minicomputer users, the number of terminals was used to derive an equivalent number of microcomputers.

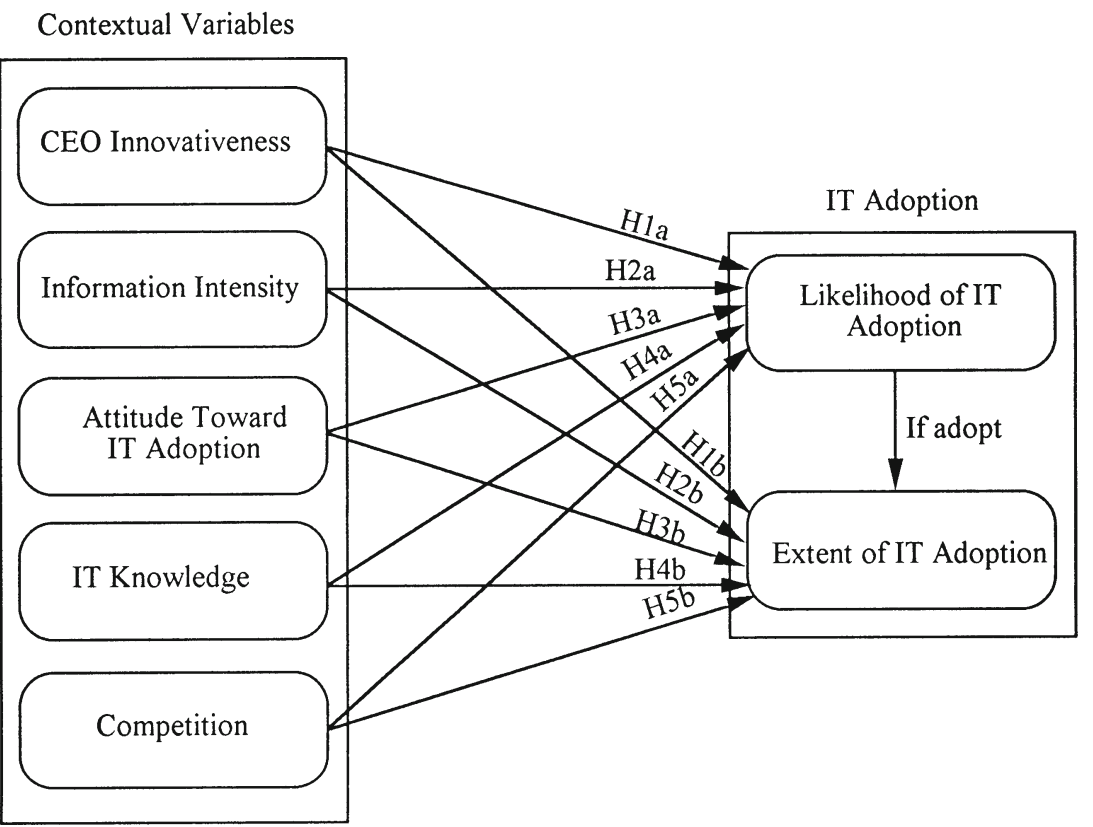

Figure 1 Research model.

\subsection{CEO innovativeness}

In a small business, the CEO is usually the owner-manager. As the CEO is the main decisionmaker, the characteristics of the CEO are crucial in determining the innovative attitude of the small business (Rizzoni, 1991). The CEO's qualities are the determinants of the overall management style of the business (Rothwell, 1977). It is the role adopted by the CEO that determines the innovativeness of the business (Cannon, 1985). In Kirton's (1976) theory of innovativeness, he contended that everyone can be located on a continuum ranging from an ability to do things better to an ability to do things differently. He called the two extreme ends of the continuum adaptors and innovators respectively. In the case of a small business, the adaptor CEO would seek solutions that have already been tried and understood. On the other 
hand, the innovator CEO would prefer solutions that change the structure in which the problem is embedded - in other words, solutions that have not been tried out and are therefore risky. Unless the CEO has the will to innovate, there is little that others can do to expedite IT adoption or increase the extent of IT adoption.

Hypothesis 1a: The more innovative the CEO, the greater the likelihood of IT adoption. Hypothesis $1 b$ : The more innovative the CEO, the greater the extent of IT adoption.

\subsection{Information intensity}

The information processing theory of Galbraith (1973) concentrates on the processes through which the environment influences a business' actions. The degree to which information is present in the product or service of a business reflects the level of information intensity of that product or service. Businesses in different sectors have different information processing needs and those in more information-intensive sectors are more likely to adopt IT than those in less information-intensive sectors (Yap, 1990). For instance, travel agencies are more informationintensive, as their main functions are to process and package tour information. Further, the greater the information intensity, the greater the potential for strategic uses of IT in a business (Porter and Millar, 1985).

Hypothesis 2a: The greater the information intensity of the product/service, the greater the likelihood of IT adoption.

Hypothesis 2b: The greater the information intensity of the product/service, the greater the extent of IT adoption.

\subsection{Attitude toward IT adoption}

According to Rogers' (1983) innovation theory, formation of a favourable or unfavourable attitude towards an innovation takes place before a decision to adopt is made. In the case of a small business, the CEO is the chief decision-maker. Hence, the CEO's perception toward IT adoption is of prime importance. As IT is a new innovation to the CEO, he or she has no way of knowing whether it will be superior to existing methods of operations. A degree of uncertainty exists as adoption of IT is risky, and each CEO will perceive the degree of risk or uncertainty associated with IT differently. If the CEO perceives the benefits of IT adoption outweigh the risks, then the business is more likely to adopt IT.

Hypothesis 3a: The more positive the attitude toward IT adoption, the greater the likelihood of IT adoption.

Hypothesis 3b: The more positive the attitude toward IT adoption, the greater the extent of IT adoption.

\subsection{IT knowledge}

Attewell (1992) conceptualized the diffusion of complex technological innovations in terms of decreasing knowledge barriers. Owing to obstacles with developing the necessary skills and technical knowledge, many businesses are tempted to postpone adoption until the barriers to 
adoption are lowered or circumvented. The implication of this theory is that overcoming the lack of knowledge of the innovation will lead to greater likelihood of adopting the innovation. Typically, small businesses are lacking in IT knowledge and technical skills (DeLone, 1988; Gable, 1991). Many of them rejected the notion that IT could be of any use to their businesses as they had no idea of the benefits that IT could potentially offer. If the IT knowledge barrier of small businesses could be lowered (e.g. more IT knowledgeable employees), they may be more willing to adopt IT.

Hypothesis 4a: The greater the level of IT knowledge, the greater the likelihood of IT adoption.

Hypothesis 4b: The greater the level of IT knowledge, the greater the extent of IT adoption.

\subsection{Competition}

By competition, we mean the business environment in which the business operates. Economists generally believe that competition increases the likelihood of innovation adoption (Kimberly and Evanisko, 1981; Link and Bozeman, 1991). It is tough rivalry that pushes businesses to be innovative. Empirically, studies have shown that more intense competition is associated with higher adoption rate (Benvignati, 1982; Globerman, 1975; Levin et al., 1987). Porter and Millar (1985) suggested that by adopting IT, businesses will be able to compete in three ways. IT can change the industry structure and, in so doing, alter the rules of competition. IT can also create competitive advantage by giving businesses new ways to outperform their rivals. Finally, IT spawns new businesses, often from within existing operations of the business. Therefore, a business in an environment that is more competitive would feel a greater need to turn to IT to gain a competitive advantage. On the other hand, a business in a less competitive environment would not be faced with a push to be innovative.

Hypothesis 5a: The greater the level of competition, the greater the likelihood of IT adoption.

Hypothesis 5b: The greater the level of competition, the greater the extent of IT adoption.

\section{RESEARCH METHODOLOGY}

\subsection{Data collection procedure}

In this study, the criteria for defining a small business are adopted from the Association of Small and Medium Enterprises (ASME) in Singapore. A small business is one that satisfies at least two of the following criteria: (1) the number of employees in the business should not exceed 100; (2) the fixed assets of the business should not exceed $\mathrm{S} \$ 12$ million (S\$1.00=US\$0.60 approximately); and (3) the annual sales of the business should not exceed S\$15 million.

The names and addresses of 800 small businesses which fulfil the ASME criteria were obtained from a small business database maintained by the National Computer Board (NCB) in Singapore. The NCB is the main government agency overseeing the promotion of IT to improve productivity and competitiveness in all sectors of the economy. Although the number 
of businesses supplied by the NCB was large, the proportion of adopters and nonadopters of IT may not be balanced as most of the businesses supplied by the NCB would have adopted IT. Hence, 400 additional businesses were selected at random from the telephone directory.

One questionnaire was designed for data collection. The questionnaire was initially pilottested in five small businesses. Based on feedback from these small businesses, minor modifications were made to the questionnaire. The final questionnaire was mailed to the CEOs of the small businesses in the survey sample. A covering letter explained the purpose of the survey and requested the CEO to return the completed questionnaire within three weeks in a pre-paid reply envelope. The respondents were assured of the confidentiality of their responses.

Of the 1200 questionnaires mailed out, 294 questionnaires were returned. However, 122 questionnaires were returned uncompleted as the businesses had changed their addresses or were no longer in operation. The remaining 172 questionnaires gave an effective response rate of $16 \%$. This response rate is considered reasonable notwithstanding that the survey was unsolicited. Responses from 6 businesses were excluded from the final sample as they did not fulfil the criteria of a small business, resulting in 166 usable questionnaires. To ensure that these responses were representative of the larger population, nonresponse bias was assessed by comparing early respondents with late respondents in terms of three key organizational characteristics of the sample. The three characteristics were number of employees, fixed assets, and sales turnover. T-tests showed no significant difference between the two groups of respondents at the $5 \%$ significance level, suggesting that nonresponse bias is not a problem. As the CEO is typically the owner-manager in a small business, it is reasonable to assume that the current CEO is the same CEO who decided on IT adoption.

\subsection{Measurement of the variables}

Standard instruments were utilized as far as possible. Where no standard instruments exist, the research variables were operationalized in close consultation with experienced IS researchers (see Appendix A). CEO innovativeness was measured by the Kirton's (1976) AdaptionInnovation Inventory (KAI) instrument. The KAI is a list of 32 items that is descriptive of the adaption-innovation scale to measure a person's innovativeness. Attitude toward IT adoption was measured by Moore and Benbasat's (1991) instrument. This instrument was adapted to the small business context. The operationalizations of the remaining research variables were developed specially for this study. All perceptual items were measured by 5 -point Likert scales representing a range from 'Strongly disagree' to 'Strongly agree'.

\subsection{Instrument validation}

For each composite research variable, the reliability or internal consistency was assessed by calculating Cronbach's alpha coefficient (see Table 1). All the reliability coefficients were at least 0.70 , suggesting that the research variables were reliable (Nunnally, 1978). The construct validity of the specially-developed research variables was examined by factor analysis. A factor analysis indicated that all the factor loadings were greater than the cut-off point of 0.50 as recommended by Nunnally (1978) and the items loaded on their hypothesized variables. Hence, we were confident that construct validity had not been violated. For subsequent statistical analysis, the score for each composite research variable was the sum of a 
respondent's scores for items defined to measure that variable. Missing data were estimated by using means from the instruments where the items were completed.

Table 1 Descriptive statistics

\begin{tabular}{|c|c|c|c|c|c|}
\hline Variable & $\begin{array}{r}\text { Adopter } \\
\text { Mean }\end{array}$ & $\frac{n=120)}{t d d D e v}$ & $\frac{\text { NonAdo }}{\text { Mean }}$ & $\frac{\operatorname{pter}(n=46)}{\text { Std Dev }}$ & $\begin{array}{c}\text { Reliability } \\
\text { Cronbach alpha }\end{array}$ \\
\hline CEO Innovativeness & 96.3 & 12.2 & 91.4 & 13.0 & 0.81 \\
\hline Information Intensity & 11.4 & 3.0 & 10.6 & 3.4 & 0.89 \\
\hline Attitude Toward Adoption of IT & 79.9 & 9.8 & 71.3 & 16.2 & 0.88 \\
\hline IT Knowledge & 5.5 & 1.9 & 4.3 & 2.0 & 0.75 \\
\hline Competition & 10.9 & 2.8 & 11.5 & 2.6 & 0.70 \\
\hline
\end{tabular}

Table 2 Sample characteristics

\begin{tabular}{lc}
\hline & Frequency \\
\hline Sector & 49 \\
Manufacturing & 46 \\
Commerce & 71 \\
Service & \\
Hardware & 61 \\
Microcomputers only & 9 \\
Minicomputers only & 15 \\
Mini and microcomputers & \\
Software Application & 88 \\
Accounting & 70 \\
Sales & 68 \\
Inventory control & 52 \\
Purchasing & 51 \\
Personnel and Payroll & 18 \\
CAD/CAM & 8 \\
MRP & 6 \\
EDI & 9 \\
Others & \\
\hline
\end{tabular}

\section{DATA ANALYSIS}

\subsection{Characteristics of sample}

$72 \%$ of the responding sample had adopted IT. This figure corresponded closely with the national average of $68 \%$ for businesses with less than 100 employees, giving further confidence about the representativeness of the sample (National Computer Board, 1993). The sample characteristics of the 166 small businesses are shown in Table 2. The businesses 
sampled were in the manufacturing, commerce, and service sectors. The distribution of business sectors is a reflection of the profile of small businesses in Singapore. On hardware, the majority of the businesses had microcomputers only. Finally, most of the businesses had implemented operational and management applications such as accounting systems, sales, inventory control, purchasing, personnel and payroll.

Table 3 Pearson correlation matrix for likelihood of IT adoption

\begin{tabular}{llllll}
\hline Variable & (1) & (2) & (3) & (4) & (5)
\end{tabular}

(1) CEO Innovativeness

(2) Information Intensity $\quad-0.008$

(3) Attitude toward IT Adoption $\quad-0.017 \quad 0.404^{* * *}$

(4) IT Knowledge $\quad 0.130^{*} \quad 0.291^{* * *} 0.459^{* * *}$

(5) Competitiveness of Environment $0.038 \quad 0.340^{* * *} \quad 0.203^{* * *} \quad 0.043$

(6) Likelihood of IT Adoption $\quad 0.192^{* * *} 0.149^{* *} \quad 0.302^{* * *} 0.313^{* * *}-0.080$

${ }^{* * *} \mathrm{p}<0.01 ;{ }^{* *} \mathrm{p}<0.05 ;{ }^{*} \mathrm{p}<0.10$

Table 4 Pearson correlation matrix for extent of IT adoption (IT adopters only)

\begin{tabular}{lccccc}
\hline Variable & (1) & (2) & (3) & (4) & (5) \\
\hline (1) CEO Innovativeness & & & & & \\
(2) Information Intensity & 0.111 & & & & \\
(3) Attitude toward IT Adoption & 0.104 & 0.044 & & & \\
(4) IT Knowledge & 0.010 & $0.184^{*}$ & $0.250^{* *}$ & & \\
(5) Competition & 0.043 & $0.244^{* *}$ & 0.050 & -0.126 & \\
(6) Extent of IT adoption & 0.105 & $0.230^{* *}$ & 0.001 & $0.356^{* * *}$ & -0.119 \\
\hline
\end{tabular}
${ }^{* * *} \mathrm{p}<0.01 ;{ }^{* *} \mathrm{p}<0.05 ;{ }^{*} \mathrm{p}<0.10$

\subsection{Correlation matrices}

The Pearson correlation matrix for likelihood of IT adoption was examined for the extent of multicollinearity problems (see Table 3). The highest squared correlation among the independent variables was 0.21 between attitude toward IT adoption and IT knowledge. None of the squared correlations was close to 0.80 to suggest a problem with multicollinearity among the research variables (Hair et al., 1992). Similarly, the Pearson correlation matrix for extent of IT adoption was examined (see Table 4). The highest squared correlation among the 
independent variables was 0.06 between attitude toward IT adoption and IT knowledge. Again, there was no evidence of multicollinearity among the research variables.

\subsection{Hypotheses testing}

The individual hypotheses with regard to the decision to adopt IT were tested by using logistic regression (see Table 5). It is the appropriate statistical technique when the dependent variable is categorical (e.g. adopters or nonadopters) and the independent variables are interval data (Hosmer and Lemeshow, 1989). Based on the goodness-of-fit statistic $\left(\chi^{2}=124.82\right.$, d.f. $=134$, $\mathrm{p}=0.703$ ), the model was not significantly different from the perfect model. The results supported hypotheses 1a, 3a, and 4a. The likelihood of IT adoption was significantly associated with CEO innovativeness, attitude toward IT adoption, and IT knowledge. Competition and information intensity were not significantly related to the decision to adopt IT.

Table 5 Logistic regression for likelihood of IT adoption

\begin{tabular}{llccc}
\hline Dependent & Independent & $B$ & Wald & $p$ \\
\hline $\begin{array}{l}\text { Likelihood of } \\
\text { IT adoption }\end{array}$ & CEO innovativeness & 1.789 & 7.273 & $0.007^{* * *}$ \\
& Information intensity & 0.267 & 1.174 & 0.279 \\
& Attitude toward IT adoption & 1.257 & 8.161 & $0.004^{* * *}$ \\
& IT knowledge & 0.847 & 8.731 & $0.003^{* * *}$ \\
& Competition & -0.413 & 2.107 & 0.147 \\
\hline
\end{tabular}

-2 $\log$ likelihood: $\chi^{2}=119.047 ; p=0.818 ;$ Goodness of fit: $\chi^{2}=124.820 ; p=0.703$ ${ }^{* * *} \mathrm{p}<0.01 ;{ }^{* *} \mathrm{p}<0.05 ;{ }^{*} \mathrm{p}<0.10$

Table 6 Multiple regression for extent of IT adoption (IT adopters only)

\begin{tabular}{llccc}
\hline Dependent & Independent & Beta & $T$ & $p$ \\
\hline $\begin{array}{l}\text { Extent of } \\
\text { IT Adoption }\end{array}$ & CEO innovativeness & 0.157 & 1.463 & 0.148 \\
& Information intensity & 0.212 & 1.849 & $0.069^{*}$ \\
& Attitude toward IT adoption & -0.098 & -0.848 & 0.399 \\
& & & \\
& IT knowledge & 0.373 & 3.274 & $0.002^{* * *}$ \\
& Competition & -0.072 & -0.651 & 0.518 \\
\hline
\end{tabular}

R-squared $=0.268 ; \mathrm{F}=4.906 ; \mathrm{p}=0.001$ ${ }^{* * * *} \mathrm{p}<0.01 ;{ }^{* *} \mathrm{p}<0.05 ;{ }^{*} \mathrm{p}<0.10$ 
The hypotheses relating to the extent of IT adoption were tested by using multiple regression (see Table 6). This technique is appropriate when the dependent variable is of interval scale (Hair et al., 1992). The results supported hypotheses $2 \mathrm{~b}$ and $4 \mathrm{~b}$. The extent of IT adoption was significantly associated with IT knowledge at the 0.05 level. There was also a weak relationship between extent of IT adoption and information intensity $(p=0.069)$. CEO innovativeness, attitude toward IT adoption, and competition were not significantly related to the extent of IT adoption.

\section{DISCUSSION}

\subsection{Likelihood of IT adoption}

For small businesses, IT adoption is dependent on the level of CEO innovativeness, attitude toward IT adoption, and IT knowledge. IT represents a radical innovation that is complex and requires a large outlay of financial resources. If the adoption is not successful, the small business could suffer irreparable damages that it may not be able to recover from. Hence, IT adoption is a risky venture. Only CEOs who are more innovative would be willing to take the risk of adopting IT in their businesses.

Small businesses with more positive attitude toward IT adoption are more likely to adopt IT. This result provides support for Rogers' (1983) innovation theory in a small business context. Some of the essential attributes of the innovation which affect the formation of attitude include relative advantage, compatibility, complexity, trialability, and observability. If the innovation is viewed as better than the existing system, is consistent with the needs of the adopting business, is easy to use and understand, allows for experimentation, and the results are easily demonstrable, then there is a higher chance that a favourable attitude toward the innovation is formed. In the context of IT adoption by small businesses, those CEOs who perceive IT adoption to be beneficial to their businesses would be more likely to adopt IT.

In addition, small businesses that are more knowledgeable about IT are more likely to adopt IT. This is consistent with Attewell's (1992) theory of lowering knowledge barriers. To the extent that the small business can lower its knowledge inadequacies, it will facilitate the path to IT adoption. Dewar and Dutton (1986) have found that extensive knowledge is important for the adoption of technical process innovation. Lack of knowledge of the IT adoption process and insufficient awareness of the potential benefits may inhibit small businesses from adopting IT (Senn and Gibson, 1981). To address this, small businesses may supplement their inadequate IT knowledge by engaging external IT experts such as consulting firms and IT vendors (Thong et al., 1994). The external IT experts can act as Attewell's (1992) 'supplyside organizations' that help to lower the innovation risk of the small businesses.

Finally, information intensity and competition do not have any significant direct effects on the decision of small businesses to adopt IT. However, there is evidence that they may have indirect effects on adoption of IT through attitude toward IT adoption. Attitude toward IT adoption is positively correlated with both of these variables. Thus, we speculate that information intensity and competition may influence the business perception toward IT adoption, resulting in the decision to adopt IT. More research needs to be conducted before we can draw more concrete conclusions. 


\subsection{Extent of IT adoption}

There is a possibility that our results may be confounded as some small businesses may have adopted more IT products due to their size. To determine the extent of this problem, we examined the Pearson correlations between organization size, using number of employees as a surrogate measure, and the independent variables. No significant correlation was found, suggesting that organization size was not a confounding variable.

The most significant variable that determines the extent of IT adoption is IT knowledge. Small businesses with greater IT knowledge are likely to use IT more extensively. This finding is again consistent with Attewell's (1992) conceptualization of innovation diffusion as a process of lowering knowledge barriers. As most small businesses do not have a formal internal IT department, they usually computerize with the aid of external IT experts such as consultants or IT vendors. Attewell (1992) suggested that the relationship between the innovation suppliers and the adopting businesses will go beyond selling, and will become structured around the task of reducing knowledge hurdles. When the small business accumulate more IT knowledge through learning by using, it will lower its IT knowledge barriers and be more confident in adopting other IT products. Widespread, routinized, and effective use of the innovation is needed before additional adoption (Fichman and Kemerer, 1993).

The second variable that affects the extent of IT adoption is information intensity. The greater the information intensity of the product or service which the small business is involved in, the greater the extent of IT adoption. This provides some support for the information processing theory. Galbraith (1973) found that when businesses take on uncertain tasks, such as scanning and processing complex information about new innovations, they have to manage the increase in information load with various design strategies. Similarly, a small business dealing with a product or service with high information intensity can make more extensive use of IT to meet its information processing needs.

Contrary to our hypotheses, CEO innovativeness, attitude toward IT adoption, and competition do not have any direct significant effects on the extent of IT adoption in small businesses. While CEO innovativeness and attitude toward IT adoption may influence the initial decision to adopt IT, they do not have any effect on the extent of IT adoption subsequently. This suggests that Attewell's (1992) theory of lowering knowledge barriers takes precedence over individual innovativeness and attitude after the initial IT adoption. In the case of competition, it appears to have no direct 'push' for businesses to increase the extent of IT adoption. However, competition may have an indirect effect on the extent of IT adoption through information intensity. Competition is positively correlated with information intensity $(r=0.244, p<0.05)$. Further research is needed to study this relationship.

\section{CONCLUSION}

Based on theories from the innovation literature, this paper has developed and tested a model of IT adoption in small businesses. The results show partial support for the model. Small businesses that have innovative CEOs, possess more positive attitude toward IT adoption, and are more knowledgeable about IT, are more likely to adopt IT. There are also some evidence that information intensity and competition may have indirect effects on the decision to adopt 
IT. However, only IT knowledge and information intensity are determinants of the extent of IT adoption. This paper has also provided evidence of the efficacy of applying technological innovation literature to the study of IT adoption.

Finally, the limitations of this study are discussed. First, due to the cross-sectional nature of the study, direction of causality can only be inferred. It is not possible to measure directly the perception of the CEO at the time of IT adoption. This is ameliorated to some extent by requesting the respondent to ascertain his or her perceptions before IT adoption. However, we cannot be completely certain that the respondent can back-track his or her mind uninfluenced by the experience of IT adoption to what the state was before adoption of IT. Longitudinal studies need to be conducted to determine the causal links more explicitly. Second, this study has investigated a subset of the variables found to be important in other technological innovations. There are other contextual variables such as performance gap, organization culture and government regulation (Ettlie, 1983; Kautz, 1995; Yap et al., 1994) that may be potential determinants of IT adoption in small businesses. Future research should examine these possibilities.

\section{REFERENCES}

Alpar P. and Reeves S. (1990) Predictors of MS/OR application in small businesses. Interfaces, 20(2), 2-11.

Attewell P. (1992) Technology diffusion and organizational learning: the case of business computing. Organization Science, 3(1), 1-19.

Benvignati A.M. (1982) Interfirm adoption of capital-goods innovations. The Review of Economics and Statistics, 64, 330-335.

Cannon T. (1985) Innovation, creativity and small firm organization. International Small Business Journal, 4(1), 33-41.

Cohn T. and Lindberge R.A. (1972) How management is different in small companies. American Management Association, New York.

Davis G.B. and Olson M.H. (1985) Management information systems: conceptual foundations, structure, and development. McGraw-Hall, Singapore.

DeLone W.H. (1988) Determinants of success for computer usage in small business. MIS Quarterly, 12(1), 51-61.

Dewar R.D. and Dutton J.E. (1986) The adoption of radical and incremental innovations: an empirical analysis. Management Science, 32(11), 1422-1433.

Downs G.W.Jr. and Mohr L.B. (1976) Conceptual issues in the study of innovation. Administrative Science Quarterly, 21, 700-714.

Ettlie J.E. (1983) Performance gap theories of innovation. IEEE Transactions on Engineering Management, 30(2), 39-52.

Eveland J.D., Hetzner W.A. and Tornatzky L.G. (1983) Conceptual issues in the study of innovation. IEEE Transactions on Engineering Management, 30(2), 37-38.

Freeman C. and Perez C. (1988) Structural Crisis of Adjustment: Business Cycles and Investment Behaviour, in Technical Change and Economic Theory (eds. G. Dosi et al.), Pinter Publications, New York, 38-66. 
Fichman R.G. (1992) Information technology diffusion: a review of empirical research, in Proceedings of the Thirteenth International Conference on Information Systems, Dallas, Texas, 195-206.

Fichman R.G. and Kemerer C.F. (1993) Toward a theory of the adoption and diffusion of software process innovations, in Proceedings of IFIP Conference on Diffusion, Transfer, \& Implementation of Information Technology (ed. L. Levine) Pittsburg, 23-30.

Gable G.G. (1991) Consultant engagement for first time computerization: a pro-active client role in small businesses. Information \& Management, 20, 83-93.

Galbraith J.R. (1973) Designing complex organizations. Addison-Wesley, Reading, M.A.

Globerman S. (1975) Technological diffusion in the Canadian tool and die industry. The Review of Economics and Statistics, 57(4), 428-434.

Hair J.F.Jr., Anderson R.E., Tatham R.L. and Black W.C. (1992) Multivariate data analysis. 3rd edition, Macmillian, New York.

Hosmer D.W. and Lemeshow S. (1989) Applied logistic regression. Wiley, New York.

Ives B. and Learmonth G.P. (1984) The information system as a competitive weapon. Communications of the ACM, 27(12), 1193-1201.

Kimberly J.R. and Evanisko M.J. (1981) Organizational innovation: the influence of individual, organizational, and contextual factors on hospital adoption of technological and administrative innovations. Academy of Management Journal, 24(4), 689-713.

Kautz K. (1995) Information technology transfer and implementation: the introduction of an electronic mail system in a public service organization, in Proceedings of First IFIP 8.6 Working Conference on Diffusion and Adoption of Information Technology (ed. K. Kautz and J. Pries-Heje) Oslo, 153-165.

King J.L., Gurbaxani V., Kraemer, K.L., McFarlan F.W., Raman K.S. and Yap C.S. (1994) The institutional factors in information technology innovation. Information Systems Research, 5(2), 139-169.

Kirton M.J. (1976) Adaptors and innovators: a description and measure. Journal of Applied Psychology, 61(5), 622-629.

Levin S.G., Levin S.L. and Meisel J.B. (1987) A dynamic analysis of the adoption of a new technology: The case of optical scanners. The Review of Economics and Statistics, 51, 1217.

Lind M.R., Zmud R.W. and Fischer W.A. (1989) Microcomputer adoption- the impact of organizational size and structure. Information \& Management, 16, 157-162.

Link A.N. and Bozeman B. (1991) Innovative behaviour in small-sized firms. Small Business Economics, 3, 179-184.

Moore G.C. and Benbasat I. (1991) Development of an instrument to measure the perceptions of adopting an information technology innovation. Information Systems Research, 2(3), 192-221.

National Computer Board (1993) Singapore IT usage survey 1993. National Computer Board, Singapore.

Nunnally J (1978) Psychometric Theory. McGraw-Hill, New York.

Porter M. and Millar V.E. (1985) How information gives you competitive advantage. Harvard Business Review, 63(4), 149-160.

Poutsma E.F., Van Uxem F.W. and Walravens A.H.C.M. (1987) Process innovation and automation in small and medium sized business. Delft University Press, The Netherlands. 
Rizzoni A (1991) Technological innovation and small firms: a taxonomy. International Snall Business Journal, 9(3), 31-42.

Rogers E.M. (1983) Diffusion of imnovations. Third Edition, The Free Press, New York.

Rothwell R. (1977) The characteristics of successful innovators and technically progressive firms. $R$ \& D Management, 7(3), 191-206.

Senn J.A. and Gibson V.R. (1981) Risks of investment in microcomputers for small business management. Journal of Small Business Management, 19(3), 24-32.

Thong J.Y.L., Yap C.S. and Raman K.S. (1994) Engagement of external expertise in information systems implementation. Journal of Management Information Systems, 11(2), 209-231.

Tornatzky L.G. and Fleischer M. (1990) The processes of technological innovation. Lexington Books, MA.

Welsh J.A. and White J.F. (1981) A small business is not a little big business. Harvard Business Review, 59(4), 18-32.

Yap C.S. (1990) Distinguishing characteristics of organizations using computers. Information \& Management, 18, 97-107.

Yap C.S., Thong J.Y.L. and Raman K.S. (1994) Effect of government incentives on computerisation in small business. European Journal of Information Systems, 3(3), 191 206.

Zaltman G., Duncan R. and Holbek J. (1973) Innovations and organizations. Wiley, New York.

Zmud R.W. (1982) Diffusion of modern software practices: influence of centralization and formalization. Management Science, 28(12), 1421-1431.

\section{APPENDIX}

Appendix A Examples of questionnaire items

CEO Innovativeness

I have original ideas

\begin{tabular}{ccccc}
\multicolumn{2}{c}{$\begin{array}{c}\text { Strongly } \\
\text { disagree }\end{array}$} & \multicolumn{3}{c}{$\begin{array}{c}\text { Strongly } \\
\text { agree }\end{array}$} \\
1 & 2 & 3 & 4 & 5 \\
1 & 2 & 3 & 4 & 5 \\
1 & 2 & 3 & 4 & 5
\end{tabular}

I would sooner create something new
I often risk doing things differently

\section{Information Intensity}

My company is dependent on up-to-date information

It is very important for my company to have access to reliable, relevant and accurate information

It is very important for my company to access information fast whenever we need the information

Attitude Toward Adoption of IT

Computers increase the productivity of my employees

$\begin{array}{lllll}1 & 2 & 3 & 4 & 5\end{array}$

My employees find computers easy to use

$\begin{array}{lllll}1 & 2 & 3 & 4 & 5\end{array}$

I have seen what other small companies have achieved with computers

$\begin{array}{lllll}1 & 2 & 3 & 4 & 5 \\ 1 & 2 & 3 & 4 & 5 \\ 1 & 2 & 3 & 4 & 5\end{array}$




\section{IT Knowledge}

My employees are all computer-literate

There is at least one employee who is a computer expert

I would rate my employees' understanding of computers as very good compared to other small companies in the same industry.

\section{Competition}

It is easy for our customers to switch to another company for similar services/products without much difficulty

$\begin{array}{llllll}\text { The rivalry among companies in the industry my company is operating } & 1 & 2 & 3 & 4 & 5\end{array}$ in is very intense

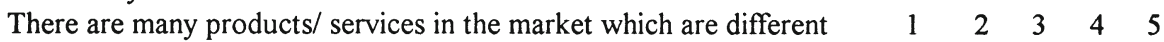
from ours but perform the same functions

\section{IT Adoption}

For each computer applications in use in your company, please put a tick against the application.

\begin{tabular}{|l|l|}
\hline \multicolumn{1}{|c|}{ APPLICATION } & \multicolumn{1}{c|}{ In-use } \\
\hline Accounting & \\
\hline Inventory Control & \\
\hline Sales & \\
\hline Purchasing & \\
\hline Personnel and Payroll & \\
\hline CAD/CAM & \\
\hline EDI & \\
\hline MRP & \\
\hline Others (Please specify) & \\
\hline & \\
\hline & \\
\hline
\end{tabular}

\section{BIOGRAPHY}

James Y.L. Thong is a doctoral candidate in the Department of Information Systems and Computer Science, National University of Singapore. He received his M.Sc. in MIS and B.Sc. (Hons) in computer science from the National University of Singapore. His research is on computerization issues that affect small business with emphasis on information technology transfer, diffusion, and implementation. He has published in the Journal of Management Information Systems, OMEGA, and European Journal of Information Systems.

Chee Sing Yap is Head of the Information Systems Division, Department of Information Systems and Computer Science, National University of Singapore. He holds a B.Sc. (Eng.) from Imperial College, London, and a Ph.D. in information systems from Cambridge University. His research interests include the use of information technology (IT) in small business, government policy and IT in Asia-Pacific countries, and telecommuting. His publications have appeared in Information Systems Research, Journal of Management Information System., Information \& Management, OMEGA, Informatization and the Public Sector, The Information Society, Journal of the Operational Research Society and European Journal of Information Systems. 